
Krakow, Poland

ORCID 0000-0002-4066-2864, a.gronek@uj.edu.pl

\title{
AN ANONYMOUS PAINTER IN THE 1680S IN WESTERN LEMKIVSHCHYNA. CHARACTERISTICS OF HIS STYLE
}

The purpose of the article is to characterise the style of the creator of the icons from Maciejowa and Krolowa Ruska from the 1680 s housed in the Regional Museum in Nowy Sacz (southern Poland) and to ascribe other surviving works in western Lemkivshchyna to his workshop. The research was conducted using the method of stylistic and comparative analysis, and, to a lesser degree, iconographic analysis. Scientific novelty. For the first time, the picturesque style of the Western Lemkoshine of the XVII century, which belonged to anonymous authors, was researched.Conclusions. As a result of research conducted in this manner, it was possible to ascribe over 40 icons to this anonymous painter, exhibited in the Regional Museum in Nowy Sacz, the Parish Museum in Grybow, the Orthodox church of Saints Cosmas and Damian in Berest and Saint Demetrius in Bogusza.

Key words: Lemkivshchyna, icons, Orthodox church, $17^{\text {th }}$ century

Ґронек Аґніешка, доктор мистецтвознавства, доцент кафредри міжнародних та політичних досліджень, Ягеллонський університет, Краків, Польща

Анонімний живописець 80-x pp. XVII століття в Західній Лемківщині. Характеристика стилю

Мета роботи. На основі ікон з Матіевій і Королевій Руській 80-х pp. XVII століття в колекціях районного музею в Новому Санчі (Південна Польща) охарактеризувати стиль творця, а потім зв'язати з його майстерні інші роботи, який збереглися на західної Лемківщини. Методика дослідження базувалася на стилістичному та порівняльному аналізі, в меншій мірі іконографрії. Наукова новизна. Вперше досліджено живлписний стиль Західної Лемківшини XVII століття, що належав анонімним авторам. Висновки. У результаті цієї дослідницької роботи анонімні художник зумів віднести більш ніж 40 ікон, розташованих в Районному музею в месте Новий Санч, Парафіяльнму музею у Грибовї, у церкви свв. Косми і Дам'яна в селі Берест і Святого Димитрія у Боґуші.

Ключові слова: Лемківщина, ікони, церква, XVII ст.

Гронэк Агнешка, доктор хабилитированный искусствоведения, доцент кафедры международных и политических исследований, Ягеллонский Университет, Краков, Польша

Анонимный художник 80-x гr. XVII века на Западной Лемкивщины. Характеристика стиля

Цель работы. На основе икон из Матеевой и Королевы Русскй 80-х гг. XVII века в коллекциях районного музея в Новым Санчи (Южная Польша) описать стиль создателя, а затем связать с его мастерскою другие работы, сохранившиеся на Западной Лемковщины. Методология Исследование проводилось на основе стилистического и сравнительного анализа, в меньшей степени иконографического. Научная новизна. Впервые исследован живописный стиль Западной Лемкившины XVII века, принадлежавший анонимным авторам. Выводы. В результате этой исследовательской работы анонимному художнику удалось приписать более 40 икон, расположенных в приходском музее в Грибовие, в церкви Св. Космы и Дамиана в Бересте и Св. Димитрия в Богуши.

Ключевые слова: Лемковщина, иконы, Церковь, XVII век

To date, icon painting in Lemkivshchyna has not been systematically and fully researched. And no wonder, as it is not an easy task for a number of reasons. First of all, the art has only survived in fragmentary form. The post-war history of Orthodox churches has contributed to this to a considerable extent, as they were deserted by their congregations due to the 'Vistula' forced resettlement operation. On the other hand, densely populated areas and a high number of village parishes necessitated the need to employ numerous painters, which resulted in the creation of a large number of works differing in style. Local artists worked here, but also itinerant ones, who would move on after completing one or two assignments. Some of the surviving works can be grouped into a few circles with distinct and original stylistic features, e.g. those from Muszyna [18] or Rybotycze [1, 9,12, 13, 14, 15, 16]. The work of particular painters can be characterised in a similar way, but only a few of them were researched in more detail $[3,4,5,16]$. Only a thorough analysis of the output of each painting workshop based in Lemkivshchyna will make it possible to recreate an in-depth and complete picture of the history of Orthodox church painting in this area. This article aims to discuss the artistic output of one of the anonymous painters working in Beskid Sadecki in the 1680 s.

There is a group of icons in the Regional Museum in Nowy Sacz whose stylistic similarity leaves no doubt as to the common workshop origin. It includes The Intercession of the Theotokos icon from Maciejowa (inv. no. MNS/1347/S, year: 1684) [8 no. 65], icons from Krolowa Ruska: St Nicholas (inv. no. MNS/822/S, year 1686 [8 no. 66], The Birth of the Mother of God (inv. no. MNS/823/S, year 1685 [8, no. 67; 6], Wise and Foolish Virgins (inv. no. MNS/824/S, year 1685 [8, no. 68], as well as a basket and a handrail of the pulpit steps from the same Orthodox Church with representations of Vladimir the Great, Saint Basil the Great, Gregory of Nazianzus, John Chrysostom (inv. no. MNS/832/S, year. 1685 [, no. 186] and The Ascension of Elijah (inv. no. MNS/831/S, year 1685 [8, no. 187]. The icon from Maciejowa was bought from a private individual in 1966, and the icons from Krolowa Ruska have been in the museum from the beginning, i.e. since 1950. In 1947 Hanna Pienkowska, the

(C) Gronek A., 2019 
then Regional Restorer of Historical Artefacts in Kraków, started securing movable historical artefacts from Orthodox churches in Lemkivshchyna, deserted after the 'Vistula' forced resettlement operation. The collected objects were first deposited in the Museum Storehouse in Muszyna, and then in the Museum in Nowy Sacz. Among 394 exhibits there were 169 icons, 12 banners, 2 kivots, 3 painted pulpits, crosses, candle holders, lecterns, wooden planks from washed off icons, empty frames, and fragments of altar and iconostasis woodcarving [8, p. 5]. This is how these works came into the possession of the Museum in Nowy Sacz. They are part of a permanent exhibition of Orthodox church art in the Gothic House in Nowy Sacz. Their stylistic similarity was noticed by the organisers of the exhibition and the catalogue. Even though it was not expressed explicitly, the fact that they were placed in the same exhibition room and close together in the catalogue corroborates this. On The Intercession of the Theotokos icon, there is a sponsorship inscription of young Andrew and his wife Anastasia from 1684, and on the St Nicholas icon - of village leader Andrew and his wife Maria from 1686, on The Birth of the Mother of God - of God's servant Konstantyn Sydoriuk and his wife Hanusia from 1685, and on the handrail of the pulpit - of village leader Wasyl, his son Tymofiej and Irena from 1685 [8, passim].

The creator of these icons had an expressive and distinctive style. He painted using a traditional technique; with distemper on a wooden plank, with representations against a neutral painted background, or engraved with a plant pattern and gilded. He placed his icons in architectural and sculptural frames and liked to close his representations with an arch at the top. Despite the traditional distemper technique, his style is innovative and is an inherent part of the painting and three-dimensional trend which coexisted in the $17^{\text {th }}$ century in Lemkivshchyna's painting with the plane-linear trend. This affiliation is corroborated by successful attempts to show the third dimension on a plane, value modelling of solids and the predominance of painting values over graphic ones.

One of the features of this painter's individual style is the way he depicts faces, especially male ones. They are oval, with long, narrow noses; round, wide open eyes and small but full and fleshy lips. The shape of the eyes, with full irises visible, and, above all, a wavy line of the eyebrows with raised inner ends creates an impression of sadness and concern. Women's faces, almost perfectly oval, have similar features, but smaller and more delicate. The only difference is the eyebrows in the form of gentle arches and an excessively high forehead.

The innovation in the rendering of the three-dimensional character of the face consists in an almost complete disappearance of patches of dark ground paint. In medieval icons it was left without the cover of chromatic layers in areas of the largest hollows and deep shadows. Here darker traces of olive ground paint only help shape the nose, separate the prominence of the chin from the lips and emphasise the arch of the eyebrow. They less often delineate the contours of the face, and only sometimes create a narrow outline of the head, ears or chin. In traditional painting the face was presented as if it was lit from the left side. It can be particularly seen in the style in which the nose is represented, whose deep shadow falls onto the left cheek. An individual trait of the Lemko painter's style is the shape of this shadow, resembling a right-angled triangle, with a clear sharp edge to the hypotenuse. He sometimes emphasises the depth of tone with whitened black. The form of highlights and their placement on the surface of the face is also new. In medieval painting three-dimensionality was achieved by applying subsequent layers of distemper and gradually lightening it up. The most convex places were indicated with lines of pure white, so called 'blikis'. They were usually applied to the right cheek; under the outer corner of the eye, the right edge of the mouth, the right side of the nose, etc. In the icons by the painter in question, highlights in the form of streaks and patches are applied to the face almost symmetrically. Its axis of symmetry is emphasised with lightening of the nose with a straight thick streak; of Cupid's bow with a clearly rounded line, and of the prominence of the chin with a round patch. White traces on both sides of the mouth help to emphasise the three-dimensional character of the full lower lip. Similarly, the prominence of round eyes is highlighted with wide bright streaks on the outer ends of the arches of the eyebrows, temples and cheek bones. The lower edges of the cheeks are emphasised with a broad application of rouge, smaller amounts of which can be noticed in some semi-shadows, e.g. on the eyelids, in the corners of the eyes, near the highlights on the bridge of the nose and on its sides, or on the prominence of the chin.

The new way of depicting eyes is also noteworthy. Wide-open eyes with the whole iris visible are frequent in medieval painting. Usually the iris was a layer of paint-free sankir (underpaint tone), enclosed with the contour or the white of the sclera, and the pupil was a regular circle delineated with black paint. All this has a conventional character - graphic and flat. However, in the icons under discussion eyes are represented realistically. A delicate blurred contour coincides with the line of the eyelashes, the whiteness of the sclera is toned down with semishadows by underlying sankir, and dark grey-black spots of iris and cornea are livened up by points of sharp white. Eyelids, modelled with white and rouge, emphasise the extraordinary three-dimensional character of these elements of the face.

The features described above can be seen in large icons, especially of St Nicholas and Church Fathers depicted at the pulpit. In other icons, where figures are small, their faces are portrayed without the use of so many formal means, but the principal modelling of the solid with the use of the colour patch has been retained. A blurred contour of olive brown only surrounds the oval of the head, delineates gentle arches of the eyebrows and sometimes separates full lips. The modelling of the face is achieved with white and rouge applied with clear layers of glaze. At first glance, this careful and thorough modelling of skin and hand complexion contrasts with the manner of presenting fabrics whose three-dimensional character is imitated with the help of wide, and seemingly casual strokes of the brush. As a result of this, fabrics make clear and thick folds or are chaotically creased. One 
of the features distinguishing this artist's style is spreading the highlights using large patches, so that fabrics look as if they were clinging to the body in that place. These highlights may be not just white but also chromatic, which usually determines the hue of the garment. It can be noticed, for example, in the icon entitled The Birth of the Mother of God, where whitened rouge was applied with a broad brush on the sleeves of Joachim's fur coat, and red streaks on one of the servants' coat at the height of her head and shoulder. Some motifs in this icon, such as tablecloths and the canopy, are presented as if the painter wanted to emphasise that colour only exists in lit places. Therefore, edges of tablecloths falling off the table top are dark and lightened chromatically only on the peaks of the folds.

A more detailed analysis, particularly of icons with larger figures, shows the dual nature of this artist's style; alongside the technique of bold and sweeping brush strokes, he also uses precise and delicate drawing. It can be seen, for example, in the icon of St Nicholas, in which he depicts white highlights on the folds of the phelonion as sashes. Similar hatching makes the uniform surface of omophorion more dynamic. This unexpected feature of the painter's meticulousness is also revealed in other decorations of this element of the bishop's vestments, primarily gold knight's crosses with an elongated stem, enclosed and shaded with black lines, as well as pearls on the edges, each of which is enclosed by the contour. The contour of the crosses is also repeated around gold applique designs on the white fabric.

With the help of hatching the icon painter included not only highlights but also a plant motif on fabrics, which can be clearly seen on the sakkos of John Golden Mouth, depicted at the pulpit in Krolowa Ruska. A sharp white contour also delineates the form of omophorion, and dynamic lines sometimes emphasise the ridges of folds, especially investments modelled with white, or which imitate the white hair of the Holy Bishops, and the ermine fur of Prince Vladimir's coat.

It is difficult to characterise the way of depicting space by the painter in question on the basis of a group of icons in the Regional Museum in Nowy Sacz. Most icons have a representative, sanctimonious character, and depict one figure against a neutral background, flat or engraved. The Ascension of Elijah has few landscape motifs and, similarly, The Wise and Foolish Virgins icon has few architectural ones. The composition of The Birth of the Mother of God was modelled on a western print included in the book entitled Officium Beatae Mariae Virginis produced in an Antwerp printing office of Plantinian in 1609 [10]. A similar composition was created by Johannes Stradanus and Adriaen Collaert, but in the foreground there is a kneeling woman with a candle, and not an angel, which indicates that the Lemko painter used the former model [20, 21]. A comparison between the icon and the prints gives us some knowledge on the attitude of the icon painter to modern ways of imitating the third dimension.

The depth of representation in the icon is built awkwardly and inconsistently. The painter did introduce additional objects (two tables) which could help him draw a geometric grid, which constitutes the basis of linear perspective, but he did not do it skilfully. The lines including the edges of the tables and the canopy over Anna's bed do not converge in one point, so each of these pieces of furniture looks three-dimensional but does not build space around itself. A traditional gold and engraved background, which reduces the depth of the composition, considerably interferes with the impression of reality. Even though the figures in the background are slightly smaller than those positioned closer, the painter combined this modern rule of presenting space on a plane with a hierarchical perspective typical of the Middle Ages, as a servant standing next to Anna is much smaller than her. He did not follow the rules of aerial perspective either, as the colour of motifs in all grounds has the same intensity.

In the print in question light plays an important role in building space. It also helps to interpret the contents of representation correctly, as it emphasises the most important motifs in the composition. Traditional icon painting does not have the actual source of light, but a conventional one, from the left side. It is particularly helpful in the modelling of the face. Objects in icons never cast a shadow beyond their own form. In the representation from Krolowa Ruska there are attempts at the introduction of the shade being cast outside. Even though candle lights in angels' hands are not the source of light (unlike in the print), nearby objects cast a shadow. Obviously, this technique was transposed from the print model. Therefore, the floor in the foreground is partly darkened, just like the table top at which Joachim is seated, and the water over which little Mary is held. This is a modern trait, taken from a particular print model, but not particularly consistently.

In the collection of icons in the Parish Museum in Grybow there are three, which are part of an Apostle tier, with representations of Thomas, John and Peter, Andrew, Jacob and Bartholomew, and also Christ on the throne. It is unclear which Orthodox church they have been transferred from to the Museum. This probably happened thanks to Jan Solak, the parish priest of St Catherine's Church in Grybow from 1921 to 1961, who protected icons from nearby Orthodox churches after the 'Vistula' operation'. The stylistic analysis indicates that they were created by the same painter. The icon of Christ is the best preserved and it has been restored in recent years.

Chris as the High Priest dressed in a colourful sakkos, the bishop's omophorion, with a characteristic, slightly too small mitre on his head, in the shape of a closed crown, is sitting on a formidable stone throne. His right hand is slightly raised in the gesture of benedicto graeca, and he is holding the Gospel in his other hand open on the quotation from Matthew 25:34 ff. Two winged angels are standing on either side of him.

\footnotetext{
-Account of Maria Filipowicz-Solarz, custodian of the Parish Museum in Grybow from 14 October 2017; with thanks for help and permission to photograph icons
} 
The way of painting uncovered body parts shows the same features which characterise icons from Krolowa Ruska: olive shades of the under paint, pinks applied in lower segments of cheeks and white patches on cheekbones, Cupid's bow, on the sides of the lower lip and on the mound of the chin. Faces have round eyes with a sad expression, a small, full mouth and a high forehead. Garments are painted in the same way as in the icons in the Regional Museum in Nowy Sacz described above; flowery patterns on the phelonion are made with hatching, and the omophorion is adorned with graphically outlined knight's crosses, and its edges are adorned with grey pearls. Figures are presented against a golden engraved background, but the throne is outlined according to the rules of geometric perspective, similarly to the floor consisting of rectangular tiles. A similar motif can be found in the icons of the Apostles. Here the relatively shallow space was built showing depth with the use of alternating light and dark rectangular tiles whose edges coincide with the grid of linear perspective. It is closed by the side of black bannister, topped with an artistically moulded ledge. Above them there is gold background, engraved with a plant motif. So the manner of presenting the icon's background combines traditional and modern features. Realism and the illusion of space convincingly built into the bottom part has been juxtaposed with an abstract, ornamental background above. No attempt was made to present tapestry or panneau, but a conscious reference was made to medieval solutions, with ideals of modern beauty expressed only in the shape of ornaments.

The figures of angels are presented in a conventional, static way, in similar poses: face on, in slight contrapposto. Round eyes, small, full lips, and olive triangular shades on the side of the nose reveal the style of the icon painter in question. Garments painted with bold brush strokes create thick and irregular folds. These parts look damaged or painted with less precision. But bright contours, still retained in places, executed dynamically and with a healthy dose of imagination, reveal a steady and bold hand. It is also worth noting here experiments with the introduction of external shadow, described already in The Birth of the Mother of God icon. Dark patches are visible on the floor, close to the Apostles' feet. It is not a realistic motif, as feet standing on the ground cannot cast this sort of shadow, but it must have been copied from an engraving.

Inscriptions help to identify Christ's disciples, but they are secondary; primary ones would have been placed on the frame of the iconostasis. The tools of passion are a western iconographic feature, used as the saints' attributes. They are represented in a realistic and three-dimensional way, which also reveals the use of engraving models.

Further works by this painter can be found in the Orthodox church of Saints Cosmas and Damian in Berest, in the iconostasis consisting of paintings created in various workshops. This Orthodox church was built in 1842 [19], but archives indicate that the parish existed here already in the 1630s at the latest, as in 1636 they note Timothy, a parish priest from Berest, [7], and in 1647 presbyter 'Father Gabriel', and in 1662 priest Stephen [2, p. 262]. It is not known when the first iconostasis in this Orthodox church was created. But what is known is that most icons associated with this Orthodox church date to the second half of the $17^{\text {th }}$ century. The Birth of the Mother of God in the Regional Museum in Nowy Sacz is the earliest icon, which has the date of 1653 (MNS/798/S0 [8, no. 54], and should be associated with the workshop of C.Z. monogrammist [3,4]. Thanks to inscriptions on the icons from Maciejowa and Krolowa Ruska, we know that the painter whose work is being characterised here worked in the 1680s. In the iconostasis in Berest, icons in the tiers of the Prophets, Apostles and the Sovereign can be ascribed to him, except the patron saint icon of Saints Cosmas and Damian. This is corroborated by stylistic features, but also iconographic ones, e.g. the representation of Christ the High Priest is almost identical with the one in the Museum in Grybow, and so are poses and attributes of the Apostles. The same can be said about the Deisis tier in Saint Demetrius Orthodox church in Bogusza. Even though this wooden church was only built in 1858, the history of Bogusza dates back to at least the $15^{\text {th }}$ century. It belonged to the Grybow non-jurisdiction district, and in 1544 Stanislaw Pieniazek from Iwanowice, granted Wallachian law to it, selling the district to Iwan Radz [17]. It is also known that in 1627 there was Orthodox priest Wasyl in the village, who bought land from Jan Kostyszak for a presbytery [2, p. 275]. The Orthodox church in Bogusza was for a while a branch of the one in Krolowa Ruska, so it is not surprising that both contain icons painted by the same artist.

On the basis of stylistic and comparative analysis it was possible to characterise the individual style of this anonymous painter, working in western Lemkivshchyna in the 1680s. It was also possible to establish that his workshop produced not just the icons from Maciejowa and Krolowa Ruska, now in the Regional Museum in Nowy Sacz, but also fragments of iconostases in the Parish Museum in Grybow, the Orthodox church of Saints Cosmas and Damian in Berest and of Saint Demetrius in Bogusza. Though he painted using medieval technique, i.e. with distemper on a plank of wood, he was very skilled at highlighting the three-dimensional character of figures, and slightly less successful at depicting the depth of composition according to modern fashion. He adopted these techniques and some iconographic motifs from western art, most likely from engravings. His artistic output is a representative example of Occidentalising Orthodox church painting in provincial circles of the early Polish Republic.

\section{תimepamypa}

1. Biskupski R., Malarstwo ikonowe od XV do pierwszej połowy XVIII wieku na Łemkowszczyźnie, „Polska Sztuka Ludowa” 39, 1985, nr $3-4$, s. $153-176$

2. Схиматісмъ всего клира руско-католического ... Епархіи Перемышльской, Перемышль 1879

3. Giemza J., Cerkwie i ikony Łemkowszczyzny, Rzeszów: Libra, 2017 
4. Gronek A., Jeszcze o ikonach monogramisty C.Z. Przyczynek do studiów nad malarstwem cerkiewnym polsko-słowackiego pogranicza, w: Sztuka pograniczy. Studia z historii sztuki, red. L. Lameński, E. Błotnicka-Mazur, M. Pastwa, Lublin-Warszawa: KUL - SHS, 2018, s. 241-259

5. Gronek A., Kolejne prace monogramisty C.Z. Ze studiów nad malarstwem ikonowym Łemkowszczyzny, w: Могилянські Читання. Збірник наукових праць, t. 22, Збереження й дослідження культурної спадщини України: люди, ідеї, візії, Київ: Національний КиєвоПечерський історико-культурний заповідник, Видавництво “Фенікс", 2017s. 206-211

6. Janocha M., Ikony w Polsce, Warszawa: Arkady, 2008

7. Księga sądowa kresu Klimkowskiego 1600- 1762, red. L. Łysiak, Wrocław 1965, s. 130. poz. 398 [w:] R. Biskupski, Berest [w:] Archiwum Cerkiewne, zespół archiwalny: Archiwum Romualda Biskupskiego, www.archiwum-cerkiewne-online.pl.

8. Maszczak, M.T. Ikony w zbiorach Muzeum Okręgowego w Nowym Sączu, Nowy Sącz; Muzeum Okręgowe w Nowym Sączu 2010

9. Nowacka J., Malarski warsztat ikonowy w Rybotyczach, „Polska Sztuka Ludowa” 1, 1962, s. 26-43

10. Officium Beatae Mariae Virginis, Antwerpia: Jan Moretus I, 1609

11. Откович В. П., Коллекция икон рыботыцких мастеров из Львовского музея Украинского искусства,,Памятники Културы, Новые Открытия" 1985, s. 323-333

12. Откович В. П., Твори риботицької народної школи малярства на Україні, у Словаччині та Румунї, w: Українське мистецтво у міжнародних зв'язках, Київ: Наукова думка, 1983, s. 90-96

13. Откович В. П., Народна течія в українському живописи XVII-XVIII ст., Київ: Наукова думка 1990

14. Откович В. П., Народне малярства Бойківщини, w: Сакральне мистецтво Бойківщини. Наукові читання памяті М. Драґана; доповіді та повідомлення, Дрогобич 1997, s. 67-70

15. Откович В. П., Риботицький осередок ікономалювання, w: Zachodnioukraińska sztuka cerkiewna, cz. II, Materiały z międzynarodowej konferencji naukowej Łańcut - Kotań 17-18 kwietnia 2004 roku, Łańcut: Muzeum - Zamek w Łańcucie, 2004

16. Przeździecka M., O małopolskim malarstwie ikonowym w XIX wieku. Studia nad epilogiem sztuki cerkiewnej w diecezji przemyskiej i na terenach sąsiednich, Wroclaw - Warszawa - Kraków: Ossolineum 1973

17. Stadnicki A., O wsiach tak zwanych wołoskich na północnym stoku Karpat, Lwów 1848

18. Szanter Z., Muszyńscy malarze ikon XVII w., w: Zachodnioukraińska sztuka cerkiewna, red. J. Giemza, Łańcut; Muzeum - Zamek w Łańcucie 2003

19. Шематизм греко-католцкого духовеньства Апостольскої Адміністрації Лемковщини 1936, Львів 1936, s. 34.

20. The new Hollstein Dutch and Flemish Etchings, engravings and woodcuts, The Collaert dynasty, Amsterdam: Sound \& Vision Publishers, 2005, nr 550.1

21. The new Hollstein Dutch and Flemish Etchings, engravings and woodcuts, Johannes Stradanus, Amsterdam: Sound \& Vision Publishers, 2008, nr 189.1

\section{References}

1. Biskupski R. [1985], Icon painting from the 15th century to the first half of the 18th century in Lemkivshchyna, "Polish Folk Art" 39 , no. $3-4$, pp. 153-176 [in Polish]

2. Schematism of entire Ruthenian Greek Catholic clergy in Przemysl Eparchy, Przemysl 1879 [in Ukrainian]

3. Giemza J. [2017], Orthodox Churches and icons of Lemkivshchyna, Rzeszow: Libra, [in Polish]

4. Gronek A. [2018], More on the icons of C.Z. monogrammist. Monograph on the study of Orthodox church paining in the PolishSlovak borderland, in: The art of the borderlands. History of art studies, ed. L. Lamenski, E. Blotnicka-Mazur, M. Pastwa, Lublin-Warszawa: KUL-SHS, pp. 241-259 [in Polish]

5. Gronek A. [2017], Further works of C.Z. monogrammist. From studies of icon painting in Lemkivshchyna, in: Mohyla Readings. Collection of academic works, Kiev, vol. 22, Protection and research of the cultural heritage of Ukraine: people, ideas and projects, pp. 206-211 [in Polish]

6. Janocha M. [2008], Icons in Poland, Warszawa: Arkady [in Polish]

7. Court records of the Klimkowski Borderland 1600-1762, ed. L. Lysiak, Wroclaw 1965, p. 130. item 398 [in:] R. Biskupski, Berest [in:] Orthodox Church Archives, archive group: Romuald Biskupski's Archive, www.archiwum-cerkiewne-online.pl. [in Polish]

8. Maszczak, M.T. [2010] Icons in the collection of the Regional Museum in Nowy Sacz, Nowy Sacz; Muzeum Okregowe w Nowym Saczu [in Polish]

9. Nowacka J. [1962], Icon painting workshop in Rybotycze, "Polish Folk Art" 1, pp. $26-43$ [in Polish]

10. Officium Beatae Mariae Virginis [1609], Antwerp: Jan Moretus I [in Latina]

11. Otkovich, W.P. [1985], Collection of icons of Rybotyche masters from the Lviv museum of Ukrainian art; cultural monuments, new discoveries, pp. 323-333 [in Ukrainian]

12. Otkovich, W.P. [1983], Works of the folk painting school in Rybotyche in Ukraine, Slovakia and Romania, in: Ukrainian Art and International Links, Kiev: Naukova Dumka, pp. 90-96 [in Ukrainian]

13. Otkovich, W.P. [1990], Folk trend in Ukrainian painting of the $17^{\text {th }}$ and $18^{\text {th }}$ century, Kiev: Naukova Dumka [in Ukrainian]

14. Otkovich, W.P. [1997], Folk painting in Boykivshchyna, in Sacred Art of Boykivshchyna. Fifth academic readings in the memory of $M$ Dragan; papers and communications, Drohobych, pp. 67-70 [in Ukrainian]

15. Otkovich, W.P. [2004], Rybotyche circle of icon painting, in: Western Ukraine Orthodox Church Art, part II, Materials from an international academic conference Lancut - Kotan 17-18 April 2004, Lancut; Muzeum - Zamek w Lancucie [in Ukrainian]

16. Przezdziecka M. [1973], On the Lesser Poland icon painting in the 19th century. Studies on the epilogue of Orthodox church art in Przemysl diocese and neighbouring areas, Wroclaw - Warszawa - Kraków; Ossolineum [in Polish]

17. Stadnicki A. [1848], On Wallachian villages on the northern slope of the Carpathian Mountains, Lviv [in Polish]

18. Szanter Z. [2003], Icon painters from Muszyna in the 17th century, in: Western Ukraine Orthodox Church Art, ed. J. Giemza, Lancut; Muzeum - Zamek w Lancucie [in Polish]

19. Schematism of Greek Catholic clergy of the Apostolic Administration of Lemkivshchyna [1936], Lviv, p. 34. [in Ukrainian]

20. The new Hollstein Dutch and Flemish Etchings [2005], engravings and woodcuts, The Collaert dynasty, Amsterdam: Sound \& Vision Publishers, no. 550.I [in English]

21. The new Hollstein Dutch and Flemish Etchings [2008], engravings and woodcuts, Johannes Stradanus, Amsterdam: Sound \& Vision Publishers, no. 189.I [in English] 